\title{
Analysis Socioeconomic Influence on the Utilization of Health Service in the Inpatient Room of Faisal Islamic Hospital Makassar
}

\author{
Muhammad Alwy Arifin ${ }^{1, *}$, Amaliah Amriani. AS $^{1}$, Muh. Yusri Abadi ${ }^{1}$, Anwar Mallongi ${ }^{2}$ and \\ Dian Saputra Marzuk ${ }^{1}$
}

\author{
${ }^{1}$ Department of Administration and Health Policy, Faculty of Public Health, Hasanuddin University, Indonesia \\ ${ }^{2}$ Department of Environmental Health, Faculty of Public Health, Hasanuddin University, Indonesia
}

\begin{abstract}
Hospitals in carrying out their role cannot be separated from problems, both from within and from outside that can interfere with the mechanism of work of the hospital in providing health services for the community. Faisal Islamic Hospital Makassar is one of the private hospitals in the city of Makassar which in the last 3 years has decreased the value of BOR. The purpose of this study was to find out the socio-economic influence on the utilization of health services in the inpatient room of Faisal Islamic Hospital Makassar. This research is a cross-sectional study. A total of 99 people were sampled in the inpatient room of Faisal Islamic Hospital Makassar by taking a sample using the purposive sampling method. Data is collected by conducting interviews with respondents. Data processing is done by frequency distribution analysis and univariate and multivariate analysis with the Binary Regression approach namely logit and probit analysis. Based on the results of the study, it was obtained that socioeconomic variables that have an influence on the utilization of health services in the Faisal Islamic Hospital Makassar is the ownership of health insurance with the results of $p$ value $<0.1$ is logit 0.299 and probit of 0.000 . For the government to evaluate the ownership of health insurance, because there are still respondents who do not have health insurance where this is not in accordance with the objectives of the National Health Insurance program.
\end{abstract}

Keywords: Utilities, social, economic, utilization of health services, hospitals.

\section{INTRODUCTION}

Hospital is a health care institution that provides individual health services in full that provides inpatient, outpatient, and emergency service (UU RI, 2009). The instrument of providing services is a hospital that must respond to the growing demands so that the hospital can compete with the institution providing health services for the community. Hospitals in their services must provide satisfaction to patients for example by providing quality services in accordance with the needs of the community (Sakilah et al., 2019).

Hospitals in carrying out their role and improving their quality are inseparable from problems, both internal and external problems that can interfere with the mechanism of work of the hospital in providing health services for the community. One of the problems in hospitals is the low level of efficiency of some hospitals in Indonesia. Hospital efficiency is one of the indicators of hospital performance, and one of the indicators to determine the level of hospital efficiency is to look at the Bed Occupancy Rate (BOR). BOR is the percentage of bed use in a given unit of time. This indicator shows the high utilization rate of hospital beds where the ideal standard for bed use rate (BOR) is $60-$ 80\% (Depkes RI, 2005).

${ }^{*}$ Address correspondence to this author at the Department of Administration and Health Policy, Faculty of Public Health, Hasanuddin University, Indonesia; E-mail: muhammadalwyarifin@gmail.com
Faisal Islamic Hospital Makassar is one of the private hospitals in Makassar City. Based on the percentage value of bed use at a certain unit of time (BOR) Faisal Islamic Hospital in the last 3 years, bor value has decreased, namely in 2017 by $69.03 \%$, in 2018 by $73.51 \%$, and in 2019 decreased to $51.44 \%$. This figure does not meet the ideal standard of hospital bed usage that has been set by the Department of Health. This indicates the need for efforts to attract the market in order to take advantage of health services in the Faisal Islamic Hospital Makassar, one of which is through analysis of factors that affect the market to benefit health services (Profil Rumah Sakit Islam Faisal, 2019).

According to Lawrence Green, the utilization of health services is influenced by 3 factors, namely predisposition factors (knowledge, attitudes, beliefs, beliefs, values, traditions, etc.), possible factors (facilities and infrastructure or health care facilities that support the occurrence of health behaviours) and reinforcing factors (knowledge, attitudes, and facilities) (Pertiwi et al., 2018). Socio-Economic is a predisposition factor in the utilization of health services. According to Kringer et al., socioeconomic status is a multi-dimensional concept where the related dimensions are the level of education, income, employment status, and age. Therefore, this study used variable age, education level, employment status, income level, and ownership of health insurance as 
independent variables that affect the utilization of health services in the inpatient room of Faisal Islamic Hospital Makassar. Based on this, the study aims to find out the socio-economic influence on the utilization of health services in the inpatient room of Faisal Islamic Hospital Makassar.

\section{MATERIALS AND METHODS}

The research design used in this research is a cross-sectional study design to find out the socioeconomic influence of patients on the utilization of health services at the Inpatient Installation of Faisal Islamic Hospital Makassar. The population in this study is the average number of inpatients at Faisal Islamic Hospital Makassar monthly which is as many as 744 people (Profile of Faisal Islamic Hospital, 2019). The large sample was obtained by calculation using the gameshow method of 99 people. Sampling using a purposive sampling method. The data collected in tabulation is then analyzed with univariate and multivariate analysis techniques using the Binary Regression approach namely logit and probit models.

\section{RESULTS}

The socioeconomic picture of respondents in this study can be seen in Table 1, where this table uses indicators of age, education, employment status, insurance ownership, and income. The distribution of research respondents at Faisal Islamic Hospital Makassar based on socioeconomic characteristics in 2020 showed that out of 99 respondents, the most were in the $26-45$-year-old age group of $27.3 \%$. The majority of respondents had a low level of education of $54.5 \%$. Then based on the employment status of respondents, the majority of respondents did not work, namely $73.7 \%$ with the majority having health insurance of $74.7 \%$. In addition, it was also found that the majority of respondents had income less than Rp. $3,103,800$, which is $57.6 \%$.

Multivariate analysis was conducted to see the influence of respondents' socioeconomic characteristics on the utilization of health services in the inpatient room of Faisal Islamic Hospital Makassar. The significance level used in this study is $1 \%, 5 \%$, and $10 \%$ where if the p-value is less than 0.01 or 0.05 or 0.1 then the independence variable affects the dependent variable significantly. The results of logit and probit analysis between dependent and independent variables showed that age had no influence on the utilization of health services in the inpatient room of Faisal Islamic Hospital when with a logit coefficient value of 0.551 and probit 0.296 (p-value $>0.1$ ). The level of education did not have a significant

Table 1: Distribution of Respondents Based on Socio-Economic Characteristics

\begin{tabular}{|c|c|c|}
\hline Respondent Characteristics & $\mathbf{n}$ & $\%$ \\
\hline \multicolumn{3}{|c|}{ Age (years) } \\
\hline 6-11 (Children) & 18 & 18.2 \\
\hline $12-25$ (Youth) & 24 & 24.2 \\
\hline 26-45 (Adult) & 26 & 26.3 \\
\hline 46-65 (seniors) & 25 & 25.3 \\
\hline$>65$ (Elderly) & 6 & 6.1 \\
\hline \multicolumn{3}{|c|}{ Education } \\
\hline Low & 54 & 54.5 \\
\hline High & 45 & 45.5 \\
\hline \multicolumn{3}{|c|}{ Job status } \\
\hline Does not work & 73 & 73.3 \\
\hline Work & 26 & 26.3 \\
\hline \multicolumn{3}{|c|}{ Health Insurance Ownership } \\
\hline Do not have & 8 & 8.1 \\
\hline Have & 91 & 91.9 \\
\hline \multicolumn{3}{|c|}{ Income } \\
\hline Less (<Rp. $3,103,800)$ & 57 & 57.6 \\
\hline Enough ( $\geq$ Rp. $3,103,800)$ & 42 & 42.4 \\
\hline
\end{tabular}


Table 2: Comparison of Logit and Probit Assumption Test Results for Socio-Economic Variables Utilization of Health Service Facilities against Independent Variables when Respondents are Gravely III

\begin{tabular}{|c|c|c|}
\hline \multirow{2}{*}{ Variable } & Logit & Probit \\
\cline { 2 - 3 } & Coefficient & 0.296 \\
\hline \hline Age & 0.551 & 0.536 \\
\hline Level of education & 0.421 & 0.299 \\
\hline Job status & 0.809 & 0.000 \\
\hline Insurance Ownership & 0.299 & 0.210 \\
\hline Income & 0.551 & - \\
\hline Constant & 0.742 & - \\
\hline Posmer-Lemeshow Chi Suare & 0.50 & 0.000 \\
\hline
\end{tabular}

Standard errors in parentheses.

${ }^{* * *} P<0.01,{ }^{* *} P<0.05,{ }^{*} P<0.1$.

influence on the utilization of health services in Faisal Islamic Hospital with a logit coefficient of 0.421 and probit of 0.536 ( $p$-value > 0.1). Variable employment status also has no significant influence on the utilization of health services in the inpatient room of Faisal Islamic Hospital with a logit coefficient of 0.809 and probit 0.299 ( $p$-value > 0.1). Insurance ownership does not affect the utilization of health services in the inpatient room of Faisal Islamic Hospital significantly with a logit coefficient value of 0.299 and probit 0.000 ( $p$-value < 0.1). families have a significant influence on the utilization of health services in the inpatient room of Faisal Islamic Hospital with a logit coefficient of 0.551 and probit 0.210 ( $p$-value $>0.1)$.

\section{DISCUSSION}

Andersen's theory of behavior explains that there are three factors that influence a person in utilizing health care, namely predisposition factors, supporting factors, and need factors. Factors used in this study are predisposition factors namely age, education level and employment status and supporting factors namely ownership of health insurance and family income. This is in accordance with research conducted by Rabbaniyah (2017) which explained that socioeconomic factors such as income, employment, and ownership of health insurance affect the utilization of health care provider facilities. The results of the analysis in this study showed that socioeconomic factors that influence the utilization of health services in the inpatient room of Faisal Islamic Hospital Makassar are ownership of health insurance.

According to santere, E., and P. (2000) theory in Rachmawati, 2019, mentioning that health care financing is always related to income where increasing family income will increase demand in the use of health services. The family's financial ability influences whether the family can pay for health services such as buying patent drugs, paying transportation costs to the service, buying groceries to support nutritional needs and other health supplies. However, since the Universal Health Coverage program is in Indonesia, almost all people have been able to access health services without cost constraints. This study obtained results that the majority of respondents who utilize health services in Faisal Islamic Hospital Makassar have less income, on the other hand, the majority of respondents use health insurance to take advantage of health services. So this research is in accordance with Saru's research that the ownership of health insurance has a significant influence and income does not have a significant influence on the utilization of health services in the Inpatient Room of Faisal Islamic Hospital Makassar.

Respondents who do not have health insurance earn the majority enough with the opinion that to get quality services must certainly pay the price in accordance with the quality they want. This is in accordance with the results of Abadi et al. (2019) research that suggests that the public considers that health services using insurance are still not good so that it has an impact on the low quality of health services. This is also evidenced by the opinion of respondents who use health insurance that the services provided by hospitals are not satisfactory, one of which requires a long wait to be given action by health workers.

Age has an influence on the utilization of health services, the older a person is, the greater the risk of 
suffering from diseases that indirectly result in higher demand for health services. Only, in this study is not only the immune factor that affects a person utilizing health services, there are other factors, namely minor to severe injuries due to accidents. So age has no influence on the utilization of health services in the Islamic Hospital Faisal Makassar. This research is in line with Wahyuni's research which states there is no significant relationship between age and the utilization of health services (Wahyuni, 2014).

The status of education is also very closely related to one's awareness and knowledge. According to Napitupilu et al., education will influence individual awareness about the importance of healthy meaning for themselves and the environment to encourage the need for health services and the selection of health services. Respondents who are in the low education category are the majority of children, namely as many as 18 people so that the level of education of respondents has no influence on the utilization of health services in the Faisal Islamic Hospital Makassar I. It's just worth noting that the decision-making where children's health care is used is determined by parents, based on the interviews of all parents of respondents of highly educated children. This is in line with Napirah's research in 2016 which stated that a person who has a higher education tends to reduce the utilization of informal health services (shamans) and increase the use of modern health services (doctors and paramedics).

Employment Status has an influence on the utilization of health services. The results obtained are in line with Kusumastiti research which states that the majority of respondents who utilize health services in the hospital are a housewife / not working because the majority of respondents are women and not working, they focus on taking care of children and their household so that they have more free time to think about their health problems.(Kusumastiti et al., 2017: Nur et al., 2016; Awal et al., 2017; Posmaningsih et al., 2018; Russeng et al., 2020)

\section{CONCLUSION}

Based on the results of the study it was concluded that socioeconomic factors that affect the utilization of health services in the Inpatient Room of Faisal Islamic Hospital Makassar are the ownership of health insurance. This shows that the problem of health financing related to family income is no longer a big problem to be considered by respondents when they want to take advantage of health services. For the government to evaluate the ownership of health insurance because there are still respondents who do not have health insurance where this is not in accordance with the objectives of the National Health Insurance program.

\section{REFERENCES}

Abadi Y., Dian S.M., Muh. Alwy A., Darmawansyah, Suci R., Muh. Al F. Analisis Kepesertaan Mandiri BPJS Kesehatan di Sektor Informal (Studi di Kota Makassar). Jurnal Manajemen Kesehatan Yayasan RS. Dr. Soetomo. 2019; 05(02): 114124 https://doi.org/10.29241/jmk.v5i2.159

Amran AR, Muh. Alwy A., Muhammad S. A qualitative Study of Accesibility Health Services among Communities on Small Islands in Makassar City. Medico-Legal Update Journal. 2020; 20(03): 881-887.

Andersen, R. et al. Equity in Health Service: Emipirical Analyses in Social Policy. Cambridge Mass, Ballinger Publishing Co.; 1975.

Depkes RI. Departemen Kesehatan Republik Indonesia. Indonesia; 2005.

Irawan B, Ainy A. Analisis Faktor-Faktor Yang Berhubungan Dengan Pemanfaatan Pelayanan Kesehatan Pada Peserta Jaminan Kesehatan Nasional Di Wilayah Kerja Puskesmas Payakabung, Kabupaten Ogan Ilir. Jurnal IImu Kesehatan Masyarakat. 2018;9(3):189-97. https://doi.org/10.26553/jikm.2018.9.3.189-197

Kusumastiti, A.R., Harjayanti, N. D., \& Haryanti, T. Analisa Segmentasi Pasar di Rumah Sakit $X$. Jurnal Medicoeticolegal dan Manajemen Rumah Sakit.2017; 06(02):130-139

Muhammad Awal, Ridwan Amiruddin, Sukri Palutturi and Anwar Mallongi, (2017) Relationships Between Lifestyle Models with Stroke Occurrence in South Sulawesi, Indonesia. Asian Journal of Epidemiology, 10: 83-88. https://doi.org/10.3923/aje.2017.83.88

Napirah MR, Rahman A, Tony A. Faktor-Faktor Yang Berhubungan Dengan Pemanfaatan Pelayanan Kesehatan Di Wilayah Kerja Puskesmas Tambarana Kecamatan Poso Pesisir Utara Kabupaten Poso. Jurnal Pengembangan Kota. 2016;4(1):29. https://doi.org/10.14710/jpk.4.1.29-39

Napitupulu IK, Carolina B, Rahmawati N. Faktor-Faktor Yang Berhubungan Dengan Pengambilan Keputusan Keluarga Dalam Pemanfaatan Puskesmas Kelurahan Pasir Kaliki Tahun 2017. Jurnal Kesehatan Prima. 2018;12(2):169-77. https://doi.org/10.32807/jkp.v12i2.190

Notoatmodjo, S. Promosi Kesehatan dan Perilaku Kesehatan. Jakarta: PT. Rhineka Cipta; 2012.

Pertiwi DP, Hamidah. Perubahan Health-Seeking Behavior Pada Pengguna Fasilitas Kesehatan BPJS Kesehatan. Jurnal Psikologi Klinik dan Kesehatan Mental. 2018;Vol. 7:84-96.

Posmaningsih, D.A., Aryasih, G.A.M., Hadi, M.C., Marwati, N.M., Mallongi, A.(2018). The influence of media booklet in behavior change of waste management in elementary school students, South Denpasar, Bali., Indian Journal of Public Health Research and Development. Volume 9, Issue 8, Pages 1506-1511. https://doi.org/10.5958/0976-5506.2018.00946.4

Profil Rumah Sakit Islam Faisal Makassar. 2019.

Rabbaniyah F, Mardiati N. Analisis Sosial Ekonomi dalam Pemanfaatan Fasilitas Kesehatan Untuk Berobat Jalan di Provindi Jawa Barat. Jurnal MKMI. 2019; 15(01). https://doi.org/10.30597/mkmi.v15i1.5888 
Rachmawati L, Sholihah IF. the Correlation Between Demand Factors and Health Care Service Utilization By Contribution Beneficiary Patients. Jurnal Administrasi Kesehatan Indonesia. 2019;7(2):185.

https://doi.org/10.20473/jaki.v7i2.2019.185-191

Rosmala Nur and Anwar Mallongi, (2016). Impact of Violence on Health Reproduction Among Wives in Donggala. Pakistan Journal of Nutrition, 15: 980-988. https://doi.org/10.3923/pin.2016.980.988

Russeng, S. S., Saleh, L. M., Awaluddin, M., \& Mallongi, A. (2020). Intervention model for barotrauma diseases to improve health and safety diving behaviors in traditional fishermen in small islands in Makassar, Indonesia. Sys Rev Pharm, 11(9), 597-600.
Sakilah N, Muhammad Alwi A., Anwar M. Differences in Services Quality Before and After Accreditation at Pamboang Health Center Majene Regency. International Journal of Science and Healthcare Reaserch'.2019; 04(02)-163-167.

Saru AAA, Muhammad Alwy ., Dian SM. Analisis Segmentasi Pasar Pelayanan Kesehatan di Instalasi Rawat Inap RS Islam Faisal Makassar. Jurnal WOPH. 2020; 01(03). https://doi.org/10.33096/woph.v1i3.89

UU RI No. 44 Tentang Rumah Sakit; 2009.

Wahyuni S. Faktor-Faktor yang Berhubungan Dengan Pemanfaatan Pelayanan Kesehatan di Puskesmas Sumber rejo Kota Balikpapan Provinsi Kalimantan Timur; 2012.

Received on 12-10-2021

Accepted on 07-12-2021

Published on 15-12-2021

https://doi.org/10.6000/1929-4409.2021.10.178

(c) 2021 Arifin et al.; Licensee Lifescience Global.

This is an open access article licensed under the terms of the Creative Commons Attribution License (http://creativecommons.org/licenses/by/4.0/) which permits unrestricted use, distribution and reproduction in any medium, provided the work is properly cited. 